\title{
Wild boar offal as a probable source of Aujeszky's disease virus for hunting dogs in Poland
}

\author{
Anna Szczotka-Bochniarz ${ }^{1}$, Andrzej Lipowski ${ }^{1}$, Anna Kycko², \\ Bartosz Sell ${ }^{3}$, Michał Ziółkowski ${ }^{4}$, Barbara Małek ${ }^{1}$ \\ ${ }^{1}$ Department of Swine Diseases, \\ ${ }^{2}$ Department of Pathology, \\ ${ }^{3}$ Department of Pharmacology and Toxicology, \\ National Veterinary Research Institute, 24-100 Pulawy, Poland \\ 4"Chiron" Veterinary Clinic, 09-410 Plock, Poland \\ anna.szczotka@piwet.pulawy.pl
}

Received: March 1, $2016 \quad$ Accepted: August 29, 2016

\begin{abstract}
Introduction: Aujeszky's disease (AD), most often related to infection of domestic and feral swine, may also concern other mammals, including dogs. The disease in carnivores, related to consumption of raw meat or offal contaminated with AD virus, is manifested by severe neurological disorders and inevitably leads to animal's death. Material and Methods: Karelian bear dog was euthanised due to nervous symptoms that started two days after participation in wild boar hunting. After exclusion of rabies the dog's carcass was subjected to standard necropsy. Tissue samples were collected for histological examination. Samples of the brain were tested for ADV by real-time PCR and virus isolation. Samples of the liver were collected for toxicological examination. Results: The presence of ADV was confirmed by real-time PCR and virus isolation. Toxicological examination revealed anticoagulant poisoning. This is the first case of Aujeszky's disease (AD) in a hunting dog in Poland after exposure to ADV from offal of wild boar. Conclusion: This infection should be taken into consideration in differential diagnosis of syndromes of neurological disorders in dogs. Since AD is found in both domestic pigs and wild boar in Poland, special care must be taken to prevent spread of infection to other species.
\end{abstract}

Keywords: Aujeszky’s disease virus, dog, wild boar, anticoagulant poisoning, Poland.

\section{Introduction}

Aujeszky's disease (AD), also known as "pseudorabies", is an infectious disease of domestic and feral swine, responsible for significant economic losses and, in some regions, restrictions in international pig trade and movement (6). The disease is caused by Suid herpesvirus 1 (SuHV1), also called “Aujeszky's disease virus" (ADV), or "pseudorabies virus", which belongs to the family Herpesviridae, subfamily Alphaherpesvirinae, genus Varicellovirus $(1,16,20)$.

ADV is able to infect all mammals except higher primates, but only pigs and wild boar are the natural hosts, able to survive the infection (16). The virus has tropism to both respiratory and nervous systems. Symptoms of disease depend on age of pigs, health status, viral strain, and infectious dose $(16,20)$.
In younger suckling pigs, up to 14 days of life, neurological symptoms are most prominent $(16,20)$. Older pigs, weaned, and adult present mostly respiratory signs. The mortality rate among these age groups is relatively low (1\%-2\%). In pregnant sows, resorption of foetuses, abortions, stillbirths and weak piglets that die within the first $48 \mathrm{~h}$ after birth are observed $(1,16,20)$.

Animals other than family Suidae, are also susceptible to ADV infection, including cattle, sheep, dogs, cats, goats, chickens, raccoons, possums, skunks, rodents, rabbits, and guinea pigs $(1,20)$. Natural cases of $\mathrm{AD}$ were also described in fox (4), wolf (30), brown bears (32), Florida panther (9), donkey, and badger (22). The disease in these species is inevitably fatal, as they represent "dead-end" hosts $(16,20)$. In carnivores AD is linked to consumption of raw meat or offal from ADVinfected animals $(9,22,33)$. 
ADV infection in dogs occurs by oronasal route, followed by transport of the virus by retrograde axonal route in the central nervous system (27). The incubation time varies from two to nine days (27). The duration of the disease is short - from 6 to $96 \mathrm{~h}$ (17). Most dogs die within four days of the onset of clinical signs that usually comprise ptyalism, trismus, anorexia, ataxia, vomitus, dyspnea, pruritus, and muscle spasms $(17,27)$.

The aim of the study was to perform histopathological, molecular, and virological examinations to verify the presence of $\mathrm{ADV}$ infection and conduct toxicological identification of common poisons in a rabies-negative hunting dog suffering from prominent neurological disorders.

\section{Material and Methods}

Clinical symptoms. Two-year-old female Karelian bear dog was admitted for consultation in a veterinary clinic due to severe nervous symptoms. This dog, vaccinated against rabies, was used in hunting. The last hunting, a wild boar battue, took place two days before the onset of clinical symptoms. The owner had six other dogs, including four of hunting breeds, but the signs of illness were only found in this single one.

The clinical symptoms started the same day, in the morning, with apathy. The dog presented abundant salivation, trismus, and pruritus of the head. Blood analysis revealed leukocytosis and elevated activity of alanine transaminase (ALT). Sedatives, antibiotics, corticosteroids, and analgetics were administered. Progressive lack of coordination and muscle paralysis were observed within $8 \mathrm{~h}$, leading to complete incoordination and inability to stand; consequently, the dog was ethically euthanised by intravenous overdose of pentobarbital sodium.

A brain sample was collected and submitted for diagnosis of rabies. The results were negative, therefore the carcass was sent for further examination to the National Veterinary Research Institute in Pulawy, Poland.

Necropsy and histopathological examination. The carcass was submitted frozen, with open skull. A section of cerebral cortex was delivered separately. Standard necropsy examination was performed. Samples of the brain, lungs, liver, stomach, spleen, and kidneys were collected, fixed in 10\% neutral-buffered formalin, routinely processed, and embedded in paraffin. The sections $(5 \mu \mathrm{m}$ thick) were stained with haematoxylineosin (HE) and subjected to histological examination.

The brain sample was also used for identification of $\mathrm{ADV}$ and the liver sample was subjected to toxicological examination.

Real-time PCR. DNA was extracted from $10 \%$ brain tissue homogenate in saline, using MagNAPure (Roche). Next, the sample was tested by SYBR Green real-time PCR (QuantiTect SYBR Green PCR kit, Qiagen) for the presence of ADV gE (formerly: gI) and $\mathrm{gD}$ (formerly: gp50) genes using primers described by
Schang and Osorio (26). Briefly, HotStarTaq (Quiagen) polymerase activation was performed at $95^{\circ} \mathrm{C}$ for $15 \mathrm{~min}$, followed by 45 cycles of denaturation at $95^{\circ} \mathrm{C}$ for $15 \mathrm{~s}$, annealing at $62^{\circ} \mathrm{C}$ for $30 \mathrm{~s}$, and elongation at $72^{\circ} \mathrm{C}$ for $30 \mathrm{~s}$. The measurement of fluorescence was performed at elongation of primers. The $10^{3.8}$ TCID $_{50}$ and $10^{4.8} \mathrm{TCID}_{50}$ of NIA-3 ADV strain served as a positive control. The specificity of amplification was confirmed by determination of PCR products' melting temperatures.

Virus isolation. Virus isolation was performed as described earlier $(1,16)$. Briefly, $3 \mathrm{~g}$ of brain tissue (pooled sections of forebrain, midbrain, hindbrain, brain stem, white and grey matter) were minced and mixed with sterile phosphate buffer saline, to obtain $10 \%$ homogenate. The sample was centrifuged (3000 rpm, $5 \mathrm{~min})$, mixed with gentamicin $(50 \mathrm{mg} / \mathrm{mL})$, and incubated for $1 \mathrm{~h}$ in darkness, at room temperature. Next, the homogenate was centrifuged $(3000 \mathrm{rpm}, 10 \mathrm{~min}$, $8^{\circ} \mathrm{C}$ ). Growth medium was removed from 24-h-old, $90 \%-100 \%$ confluent SK-6 cell line grown in $25 \mathrm{~cm}^{2}$ flask, and supernatant was transferred into the flask (10). After $1 \mathrm{~h}$ of incubation at $37^{\circ} \mathrm{C}$, the homogenate was replaced with growth medium. The cells were observed daily, for 96-120 h, for cytopathic effect.

Toxicological examination. Using a modern multiclass method based on QuEChERS technique and liquid chromatography tandem mass spectrometry (LC$\mathrm{MS} / \mathrm{MS}$ ), the liver sample was examined for the presence of rodenticides (warfarin, coumatetralyl, chlorophacinone, coumachlor, bromadiolone, brodifacoum, flocoumafen, difenacoum, diphacinone, strychnine), carbamate pesticides (aldicarb, bendiocarb, carbaryl, carbofuran, dioxacarb, propoxur), phosphoroorganic pesticides (azinphosethyl, azinphos-methyl, bromophos-ethyl, carbophenothion, chlorfenvinphos, chlorpyrifos, diazinon, dichlofenthion, dichlorvos, ethion, etrimfos, fenchlorphos, fonofos, malathion, methamidophos, methacrifos, pirimiphos-ethyl, pirimiphos-methyl, propetamphos, sulfotep, dicrotophos, dimefox, dimethoate, disulfoton, fenitrothion, formothion, iodofenphos, malaoxon, mevinphos, omethoate, paraoxon, parathion-methyl, parathion, phosalone, pyrazophos, triazophos), coccidiostats (lasalocid, monensin, narasine, salinomycin, semduramycin, maduramycin), and mycotoxins (aflatoxins B1, B2, G1, and G2, zearalenone, deoxynivalenol, HT-2, T-2, sterigmatocystin).

The LC-MS/MS system consisted of an Agilent Series 1200 HPLC system (Agilent Technologies, Germany) connected to a ABSciex API 5500 Qtrap mass spectrometer (PE Sciex, Canada). The Analyst 1.6.2 software controlled the LC-MS/MS system and processed the data.

\section{Results}

Necropsy and histopathological examination. Macroscopic examination revealed the presence of 
bloody fluid in peritoneal cavity (about $500 \mathrm{~mL}$ ), uncoagulated blood in the main vessels, severe multifocal haemorrhage and/or congestion in the lungs, segmental congestion of tracheal mucosa, severe hepatic congestion, renal congestion, enlargement of the spleen characterised by multifocal to coalescing dark red, soft, blood-filled raised areas of various sizes, and multifocal congestion and dark-red discoloration of gastric mucosa. Also, several parasites (roundworms) were found in the lumen of the jejunum.

Freezing and thawing process affected the picture of histopathological changes, especially in the nervous tissue, making it difficult to evaluate the lesions thoroughly. However, general conclusions are presented below.

Histopatologically, severe pulmonary oedema, blood vessel congestion, and blood extravasations were observed (Fig. 1). Marked congestion and haemorrhages were also present in spleen parenchyma as well as in renal cortex (Fig. 2). The gastric mucosa showed marked necrosis. Microscopic examination of the cerebral cortex revealed mainly numerous freezing artefacts, although mild gliosis was visible as well (Fig. 3).

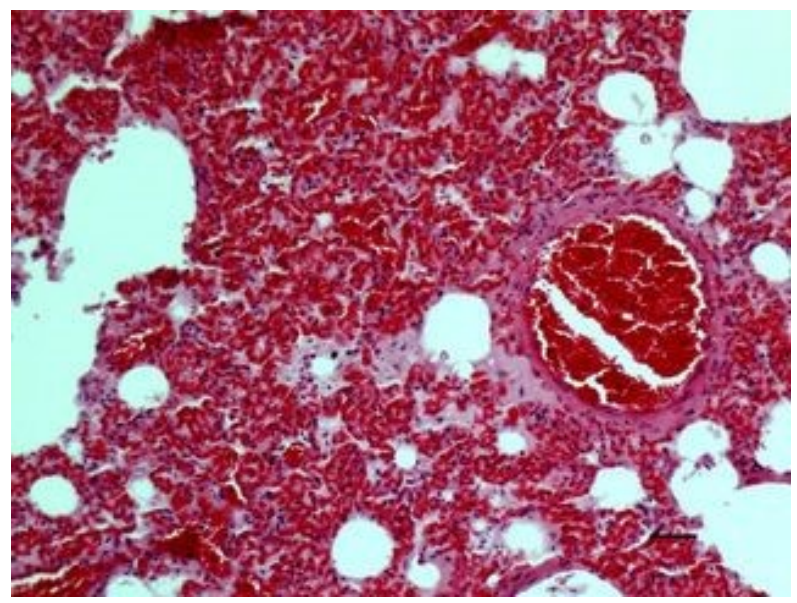

Fig. 1. Severe oedema in lungs (HE, bar: $50 \mu \mathrm{m})$

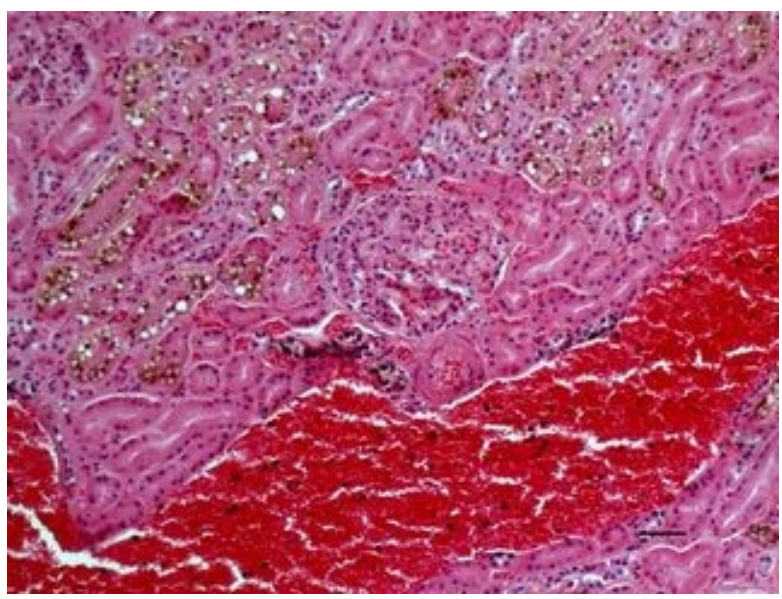

Fig. 2. Congestion and haemorrhage in renal cortex (HE, bar: $50 \mu \mathrm{m})$

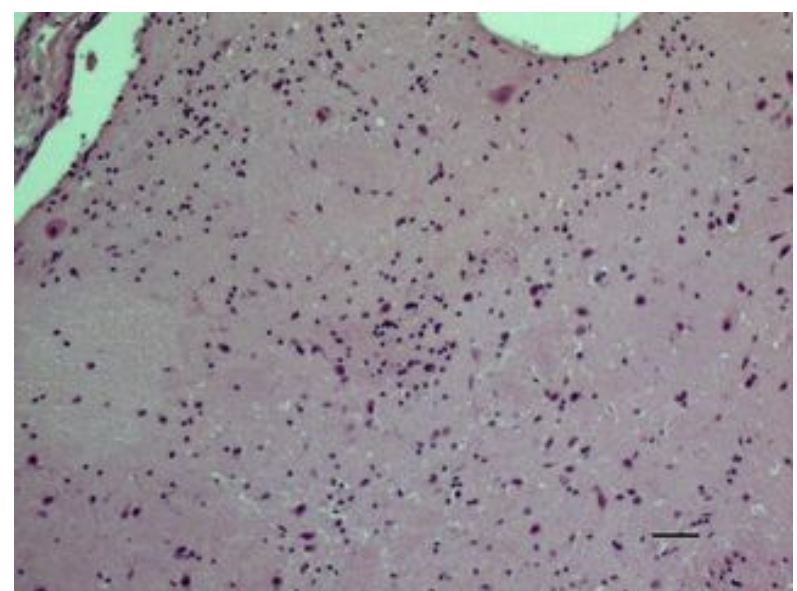

Fig. 3. Mild gliosis in cerebral cortex (HE, bar: $50 \mu \mathrm{m}$ )

Real-time PCR. The presence of ADV genetic material in the brain sample was confirmed by real-time PCR, reaching CT value of 26.28 (Fig. 4). The melting temperature of the tested sample and positive controls was $91.7^{\circ} \mathrm{C}$ (Fig. 5).

Virus isolation. The cytopathic effect was visible in the second passage of brain tissue homogenate in SK-6 cells. Initially, accumulation of birefringent cells and cell rounding up was observed, followed by formation of syncytia and cell detachment (Fig. 6A, B), while negative control cells remained intact (Fig. 6C).

Toxicological examination. Brodifacoum (433.9 $\mu \mathrm{g} / \mathrm{kg})$, bromadiolone (129.7 $\mu \mathrm{g} / \mathrm{kg})$, and difenacoum (below limit of quantification $-10.0 \mu \mathrm{g} / \mathrm{kg}$ ) were detected in the liver sample.

Other analysed compounds listed below were not detected in concentrations above the limits of quantification of the method. The substances under study included organophosphorus pesticides: bromophos-ethyl, carbophenothion, fenchlorphos, fenitrothion, parathion-methyl - $50 \mu \mathrm{g} / \mathrm{kg}$, methamidophos, iodofenphos, omethoate - $25 \mu \mathrm{g} / \mathrm{kg}$, chlorpyrifos, dichlofenthion, dichlorvos, ethion, etrimfos, fonofos, methacrifos, dimefox, disulfoton, formothion, malaoxon, paraoxon, parathion - $10 \mu \mathrm{g} / \mathrm{kg}$, azinphos-ethyl, azinphos-methyl, chlorfenvinphos, diazinon, malathion, pirimiphosethyl, pirimiphosmethyl, propetamphos, sulfotep, dicrotophos, dimethoate, mevinphos, phosalone, pyrazophos, triazophos $-5 \mu \mathrm{g} / \mathrm{kg}$; carbamate pesticides: aldicarb - $25 \mu \mathrm{g} / \mathrm{kg}$, dioxacarb - $10 \mu \mathrm{g} / \mathrm{kg}$, bendiocarb, carbaryl, carbofuran, propoxur - $5 \mu \mathrm{g} / \mathrm{kg}$; rodenticides: coumatetralyl - $50 \mu \mathrm{g} / \mathrm{kg}$, chlorophacinone, diphacinone, flocoumafen, strychnine - $25 \mu \mathrm{g} / \mathrm{kg}$, warfarin - $10 \mu \mathrm{g} / \mathrm{kg}$, coumachlor - $5 \mu \mathrm{g} / \mathrm{kg}$; coccidiostats: lasalocid, maduramycin, monensin, narasine, salinomycin, semduramycin - $25 \mu \mathrm{g} / \mathrm{kg}$; mycotoxins: deoxynivalenol, HT-2, T-2 - $50 \mu \mathrm{g} / \mathrm{kg}$, sterigmatocystin - $25 \mu \mathrm{g} / \mathrm{kg}$, aflatoxins B2, G1, and G2, zearalenone - $10 \mu \mathrm{g} / \mathrm{kg}$, and aflatoxin $\mathrm{B} 1-5 \mu \mathrm{g} / \mathrm{kg}$. 


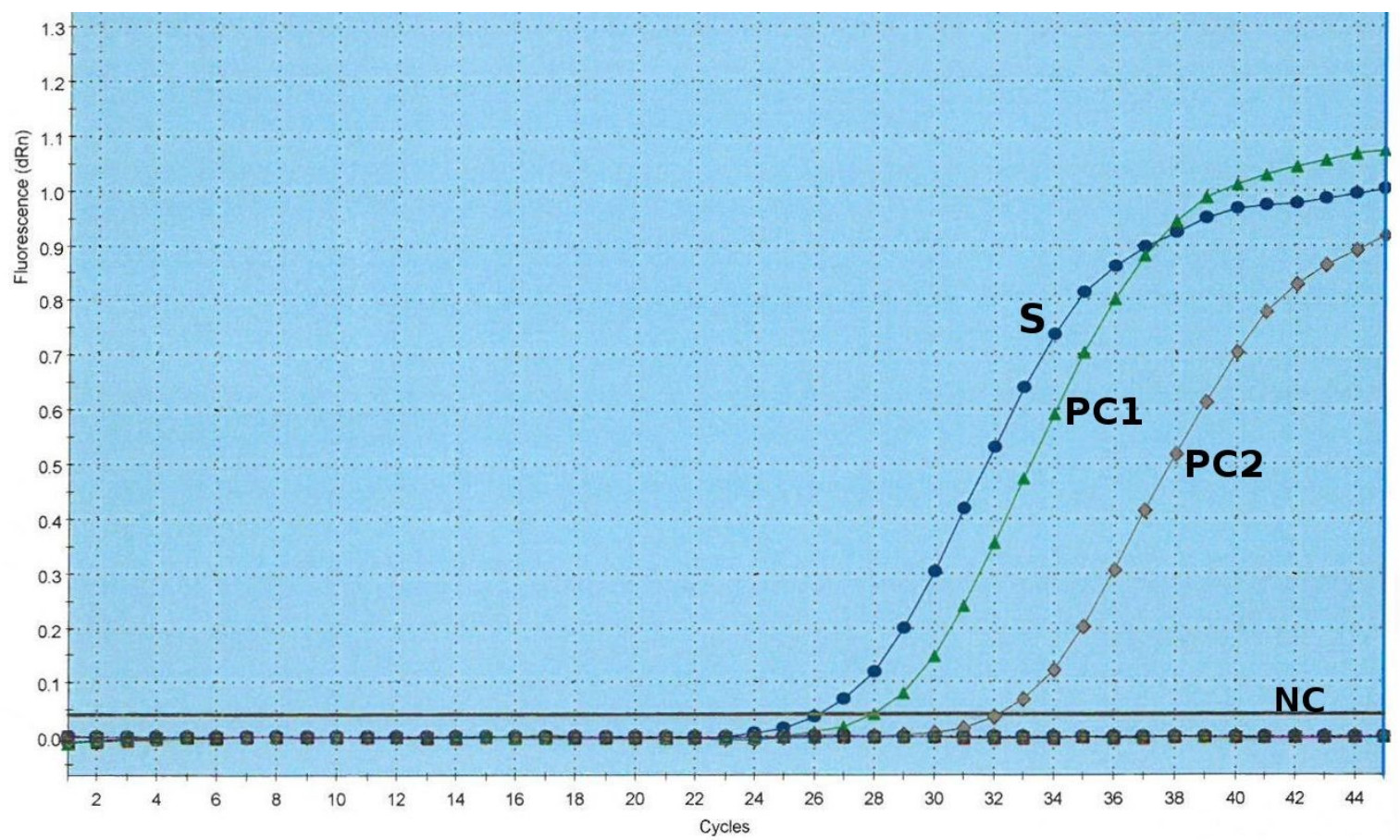

Fig. 4. Real-time PCR amplification plots for ADV detection. S - sample; PC1 - positive control 1: $10^{4,8} \mathrm{TCID}_{50}$ of NIA-3 ADV strain; PC2 - positive control 2: $10^{3,8} \mathrm{TCID}_{50}$ of NIA-3 ADV strain; $\mathrm{NC}$ - negative control

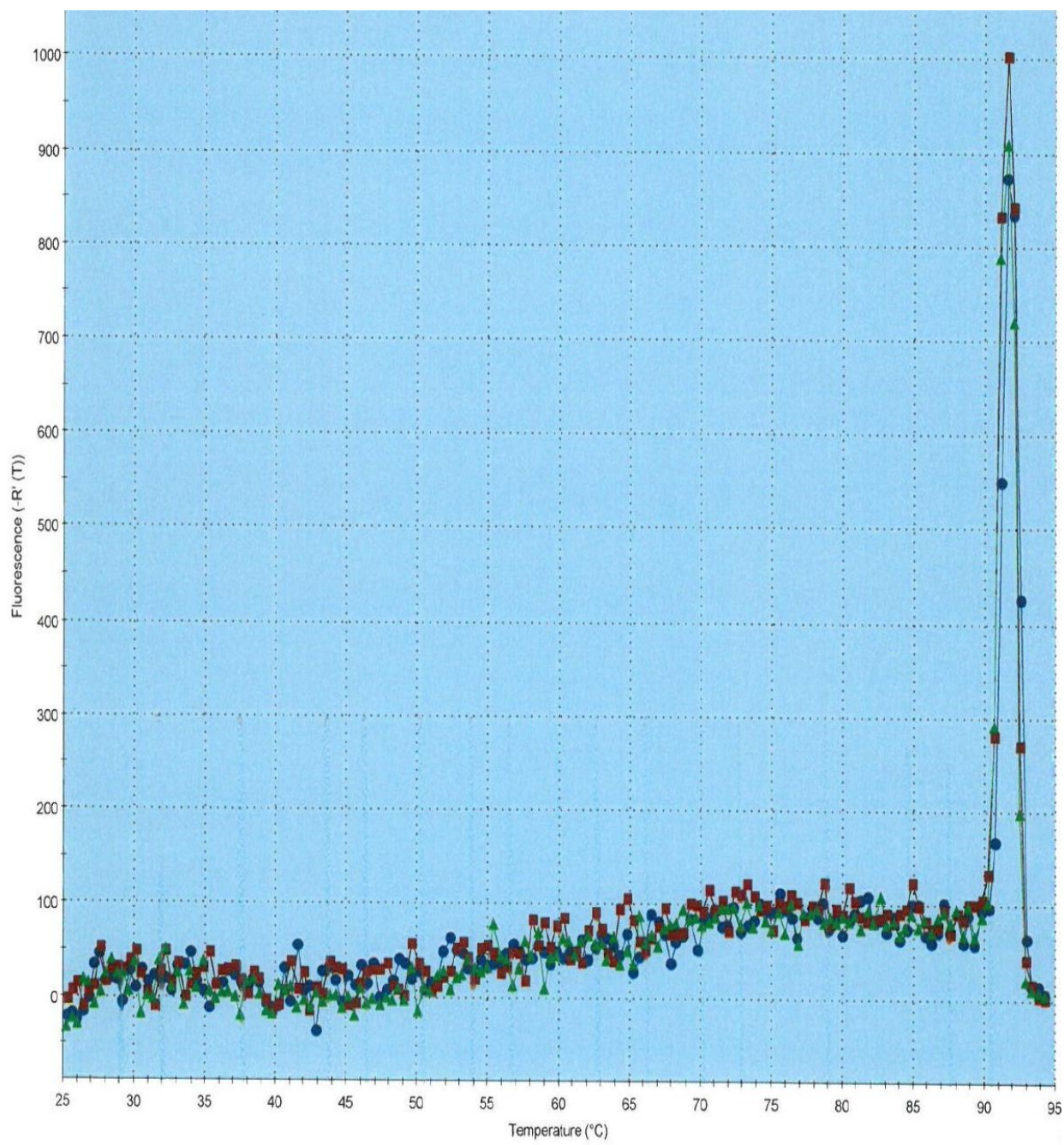

Fig. 5. The melting temperature analysis of ADV real-time PCR products 


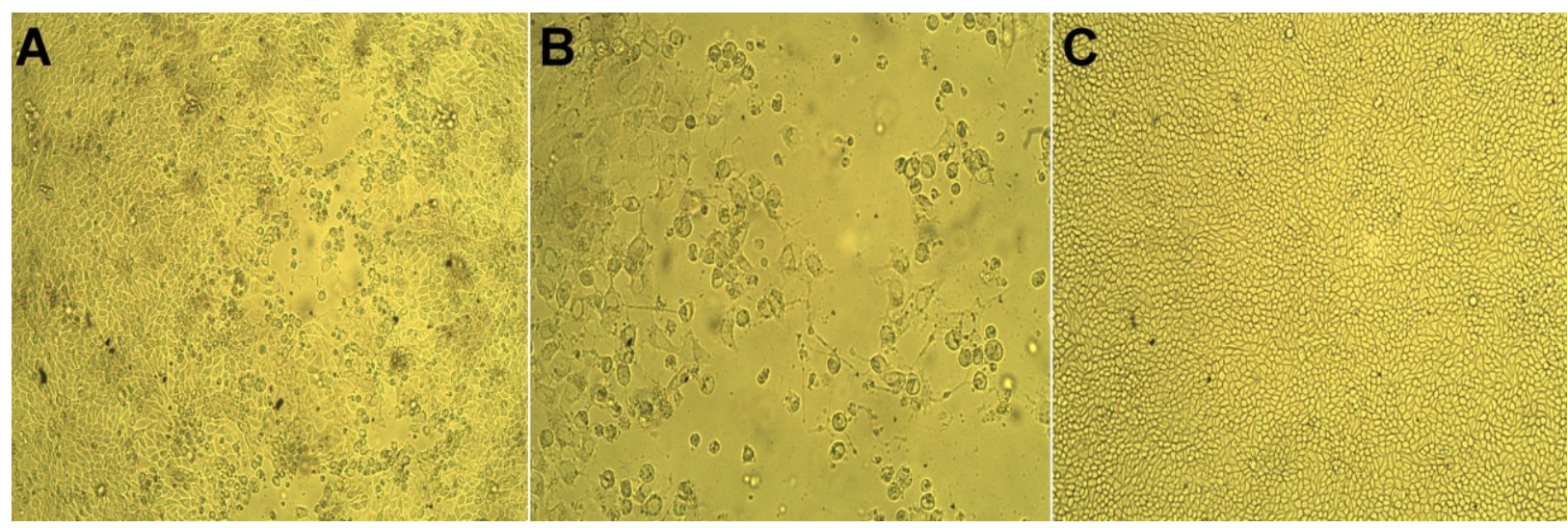

Fig. 6. Cytopathic effect in SK-6 cell line $72 \mathrm{~h}$ post infection with Aujeszky's disease virus present in dog's brain tissue homogenate: A - detachment of infected cells, rounding and formation of syncytia $(100 \times)$; B - prominent plaque formation and round cells with intercytoplasmic bridges $(200 \times)$; C -normal morphology of SK-6 cell line $(100 \times)$

\section{Discussion}

$\mathrm{AD}$ is very occasionally present in swine population in Poland $(13,14)$. The $\mathrm{AD}$ eradication programme, based on extensive serological survey, was implemented in Poland in 2008 on the basis of the Regulation of Ministry Council of 2008 (23), amended by Regulation of Ministry of Agriculture and Rural Development of 2015 (24)

Although "vaccination - eradication" programme was implemented in most regions of Poland, seropositive pigs are still found (12). The disease is also present in Polish wild boar population, posing a threat and serving as a potential reservoir and source of infection for domestic pigs $(11,15,18,29)$, as well as for other susceptible species.

Cases of $\mathrm{AD}$ in dogs in Poland were already confirmed in 1958-1960 (2). The detailed description of clinical symptoms of the disease and undertaken treatment was reported by Przymus and Kozioł (21). The most recent publication concerning AD in dogs in Poland was by Salwa (25).

In dogs infected with ADV neurological symptoms, like increased salivation, pruritus, depression, and lethargy, are observed $(5,7,11,27)$. The most prominent necropsy finding is systemic haemorrhage, leading to hypovolemic shock (33).

The disease in dogs is usually related to exposure to the virus from meat or offal of infected domestic pigs or wild boar $(5,7,18,28)$. In this particular case the infection was most likely spread from wild boar by ingestion of internal organs, e.g. during evisceration of wild boar carcass.

Brodifacoum, bromadiolone, and difenacoum detected in dog's liver are synthetic, second-generation anticoagulant rodenticides characterised by higher toxicity and longer duration of action compared to first generation compounds (19). They act as inhibitors of hepatic vitamin $\mathrm{K}_{1}$ epoxide reductase and in this way reduce synthesis of functional vitamin $\mathrm{K}_{1}$-dependent clotting factors by preventing carboxylation of glutamate and formation of $\gamma$-carboxyglutamate residues (8). They are widely used to control rodent population, but are also highly toxic to other mammals. For this reason they are the main cause of poisoning in domestic and wild animals (3), especially dogs (3, 31). The clinical symptoms of poisoning are: weakness, lethargy, dyspnea, extensive bleeding, haemoptysis, epistaxis, ecchymoses in serosal and mucous membranes, tachycardia, and weak pulse (31).

The results of this study (evidence of typical neurological symptoms, confirmation of ADV DNA in brain sample, and isolation of the virus in cell culture) unquestionably confirm that the dog suffered from AD. Although infection with ADV seems to be the major reason for observed clinical disorders and the primary cause of dog's death, the identification of anticoagulant rodenticides in the liver confirms that the dog's clinical condition was additionally complicated by poisoning.

It is, however, impossible to determine which cause occurred first, ADV infection or poisoning, as the incubation time of $\mathrm{AD}$ in canines varies from two to nine days (17). Moreover, the levels of anticoagulant rodenticides detected cannot be linked out to severity of clinical signs - or the duration of poisoning, as these substances have the ability to cumulate in the organism (31).

Anticoagulant rodenticide poisonings occur in hunting dogs and are usually linked to accidental consumption of poisoned baits for wildlife. Such scenario cannot be ruled out in this particular case.

To the best of authors' knowledge, this is the first report of $\mathrm{AD}$ in a hunting dog in Poland, suggesting infection with ADV from offal of wild boar. Additionally, this case was complicated by anticoagulant rodenticides poisoning. The major importance in these two conditions for clinicians is the partial overlap of clinical manifestations. AD should also be taken into consideration during differential diagnosis of neurological symptoms in domestic animals. 
Since AD is found in both domestic pigs and wild boar in Poland, special care must be taken to prevent the spread of the infection to other species. However, since $\mathrm{AD}$ in animals other than swine is not notifiable, the epidemiological data in domestic animals remain unknown.

Conflict of Interests Statement: The authors declare that there is no conflict of interests regarding the publication of this article.

Financial Disclosure Statement: The research was financially supported by the National Veterinary Research Institute.

Animal Rights Statement: None required.

Acknowledgements: The author's would like to thank Mrs Paulina Karkut for her skilled technical assistance.

\section{References}

1. Aujeszky's disease. OIE Terrestrial Manual, 2012, pp. 1-15, http://www.oie.int/international-standard-setting/terrestrialmanual/access-online/.

2. Bartosz B.: Aujeszky's disease in the region of Dobiegniew in the years 1958-1960. Med Weter 1962, 18, 393-396.

3. Caloni F., Cortinovis C., Rivolta C., Davanzo F.: Suspected poisoning of domestic animals by pesticides. Sci Total Environ 2016, 539, 331-336.

4. Caruso C., Dondo A., Cerutti F., Masoero L., Rosamilia A., Zoppi S., D’Errico V., Grattarola P.L., Peletto S.: Aujeszky's disease in red fox (Vulpes vulpes): phylogenetic analysis unravels an unexpected epidemiological link. J Wildl Dis 2014, 50, 707-710.

5. Cay A.B., Letellier C.: Isolation of Aujeszky's disease virus from two hunting dogs in Belgium after hunting wild boars. Vlaams Diergeneeskundig Tijdschrift 2009, 78, 194-195.

6. Commission Decision 2008/185/EC of 21 February on additional guarantees in intra-Community trade of pigs relating to Aujeszky's disease and criteria to provide information on this disease. OJ L 59, 4.3.2008, 19.

7. Cramer S.D., Campbell G.A., Njaa B.L., Morgan S.E., Smith II S.K., McLin IV W.R., Brodersen B.W., Wise A.G., Scherba G.S., Langhorn I.M., Maes R.K.: Pseudorabies virus infection in Oklahoma hunting dogs. J Vet Diagn Invest 2011, 23, 915-923

8. Furie B., Bouchard B.A., Furie B.C.: Vitamin K-dependent biosynthesis of gamma-carboxyglutamin acid. Blood 1999, 93, 1798-1808.

9. Glass C.M., McLean R.G., Katz J.B., Maehr D.S., Cropp C.B., Kirk L.J., McKeiman A.J., Everman J.F.: Isolation of pseudorabies (Aujeszky's disease) virus from a Florida panther. J Wildl Dis 1994, 30, 180-184.

10. Kasza L., Shadduck J.A., Christofinis G.J.: Establishment, viral susceptibility and biological characteristics of a swine kidney cell line SK-6. Res Vet Sci 1972, 13, 46-51.

11. Lipowski A., Pejsak Z.: Antibody prevalence of pseudorabies virus in feral pigs in Poland. Proc. $17^{\text {th }}$ International Pig Veterinary Society Congress, Ames, 2002, 223.

12. Lipowski A., Pejsak Z.: Occurrence of Aujeszky’s disease virus single-reactor pigs in Poland. Bull Vet Inst Pulawy 2015, 59, 185-190.
13. Lipowski A., Pejsak Z.: Seroprevalence of Aujeszky's disease in pigs in Poland in the years 2001-2004. Med Weter 2006, 62, 285-288.

14. Lipowski A., Związek J. Pejsak Z: Seroprevalence of Aujeszky’s disease in pigs in Poland in the years 2005-2007. Med Weter 2009, 65, 771-774

15. Lipowski A.: European wild boar (Sus scrofa L.) as a reservoir of infectious diseases for domestic pigs. Med Weter 2003, 59, 861-863.

16. Mettenleiter T., Ehlers B., Müller T., Yoon K.J., Teifke J.P.: Herpesviruses. In: Diseases of Swine, edited by WileyBlackwell, Ames, 2012, pp. 421-446.

17. Monroe W.E.: Clinical signs associated with pseudorabies in dogs. J Am Vet Med Assoc 1989, 195, 599-602.

18. Moreno A., Sozzi E., Grilli G., Gibelli L.R., Gelmetti D., Lelli D., Chiari M., Prati P., Alborali G.L., Boniotti M.B., Lavazza A., Cordioli P.: Detection and molecular analysis of pseudorabies virus strains isolated from dogs and wild boar in Italy. Vet Microbiol 2015, 177, 359-365.

19. Murphy M.J.: Rodenticides. Vet Clin North Am Small Anim Pract 2002, 32, 469-484.

20. Pomeranz L., Reynolds A.E., Hengartner C.J.: Molecular biology of pseudorabies virus: impact on neurovirology and veterinary medicine. Microbiol Mol Biol Rev 2005, 69, 462-500.

21. Przymus J., Kozioł T.: A case of Aujeszky's disease in a dog. Med Weter 1989, 45, 41.

22. Pušić I., Prodanov-Radulović J., Došen R., Stojanov I., Stojanović D., Petrović T.: Epizootical characteristics of Aujeszky's disease in Vojvodina region and biosecurity concerns. Biotechnol Anim Husb 2011, 27, 875-882.

23. Regulation of Ministry Council of 19 March 2008 concerning introducing Aujeszky's disease eradication programme. Journal of Laws of the Republic of Poland, 2008, No. 64, item 397.

24. Regulation of Ministry of Agriculture and Rural Development of 27 January 2015 concerning introducing Aujeszky's disease eradication and monitoring programme. Journal of Laws of the Republic of Poland, 2015, No. 189.

25. Salwa A.: Evaluation of the epidemiological situation of Aujeszky's disease in the Gdańsk coast area in 1987-2006. Med Weter 2008, 64, 1118-1121.

26. Schang L.M., Osorio F.A.: A quantitative technique for the study of the latency of Aujeszky virus. Rev Sci Tech Off Int Epiz 1993, 12, 505-521.

27. Schöniger S., Klose K., Werner W., Schwarz B.-A., Müller T., Schoon H.-A.: Nonsuppurative encephalitis in dogs. Vet Pathol 2012, 49, 731-734.

28. Steinrigl A., Revilla-Fernández S., Kolodziejek J., Wodak E., Bagó Z., Nowotny N., Schmoll F., Köfer J.: Detection and molecular characterization of Suid herpesvirus type 1 in Austrian wild boar and hunting dogs. Vet Microbiol 2012, 157, 276-284.

29. Szweda W., Lipowski A., Ciecierski H., Zalewski K., Pirus T.: European wild boar (Sus scrofa L.) as a reservoir of Herpesvirus suis 1. Med Weter 1998, 54, 541-544.

30. Verpoest S., Cay A.B., Bertrand O., Saulmont M., de Regge N.: Isolation and characterization of pseudorabies virus from a wolf (Canis lupus) from Belgium. Eur J Wildl Res 2014, 60, 149-153.

31. Wadell L.S., Poppenga R.H., Drobatz K.J.: Anticoagulant rodenticide screening in dogs: 123 cases (1996-2003). J Am Vet Med Assoc 2013, 252, 516-521.

32. Zanin E., Capua I., Casaccia C., Zuin A., Moresco A.: Isolation and characterization of Aujeszky's disease virus in captive brown bears from Italy. J Wildl Dis 1997, 33, 632-634.

33. Zhang L., Zhong C., Wang J., Lu Z., Liu L., Yang W., Lyu Y.: Pathogenesis of natural and experimental Pseudorabies virus infections in dogs. Virol J 2015, 12:44, doi: 10.1186/s12985015-0274-8. 